\title{
"I była matką Dziewicy Maryi i babką Boga i człowieka": kobiece genealogie w interpretacjach źródeł wiary
}

Julia Lewandowska

TEKSTY DRUGIE 2018, NR 6, S. 31-53

DOI: $10.18318 /$ td.2018.6.3

$\mathbf{O}$ d pierwszych wieków naszej ery pamięć wspólnot chrześcijańskich konstruowana i negocjowana na podstawie tworzącego się kanonu Pisma Świętego była pamięcią zasadniczo androcentryczną. Interpretacje $\mathrm{Pi}$ sma przez Ojców Kościoła i kolejnych Doktorów Kościoła utrzymywały głos kobiet poza oficjalnym dyskursem wiary, konstytutywnym dla „,wielkiej opowieści chrześcijan". Jednak wychodząc od samego rdzenia Dobrej Nowiny: wcielenia, śmierci i zmartwychwstania Zbawiciela, słowo i sprawczość kobiet stanowiły nieredukowalną część jej dziedzictwa.

Niniejszy artykuł jest moją pierwszą próbą włączenia się do dyskusji nad przewartościowaniem/zrewidowaniem roli kobiet w historii Kościoła katolickiego, jego źródłach wiary i praktyce nauczycielskiej Magisterium. Inaczej jednak niż w nurcie badań, które nie problematyzują ram ortodoksji Kościoła, a także w odróżnieniu od analiz z perspektywy teologii feministycznej, która granice ortodoksji rozmywa, w mojej analizie wycho$\mathrm{dzęz}$ dwóch odmiennych założeń metodologicznych. Po
Julia Lewandowska dr, adiunkt na Wydziale „Artes Liberales" UW. Stypendystka FNP. Odbyła staże m.in. w Spanish National Research Council w Madrycie i w ADHUC na U. de Barcelona. Zainteresowania: teologia feministyczna, historia i antropologia monastycyzmu kobiet, afekt i reprezentacja w dyskursach religijnych. Członkini Europejskiego Towarzystwa Kobiet dla Badań Teologicznych, Interdyscyplinarnego Centrum PRO RHETORICA i Projektu „Archiwum kobiet: piszące", IBL PAN. 
pierwsze, podejmuję postulat, sygnalizowany już przez Dale Spender' i Elizabeth Schüssler-Fiorenzę ${ }^{2}$, mówiący o konieczności poszerzenia aktualnej debaty o teksty dawne kobiecego autorstwa. Dzięki temu wiele szeroko komentowanych już kwestii zostaje umiejscowionych w nowych kontekstach. Tematy podejmowane przez współczesne nurty krytyki feministycznej, jak: odrzucenie androcentrycznego nazewnictwa Boga, przewartościowanie męskocentrycznej perspektywy trynitarnej czy dowartościowanie kobiecych postaci biblijnych, w tym szukanie innych niż macierzyński wymiarów mariologii, nie są wyłącznie konsekwencją XX-wiecznych ruchów emancypacyjnych i przemian mentalności. Mają bowiem długą i bogatą tradycję wśród autorek religijnych XVII, XVI, a nawet XV stulecia. Przemilczeć tę tradycję, pominąć ją, to usytuować się, dobrowolnie czy przez zaniedbanie, w pozycji osierocenia, tak często narzucanej kobiecej twórczości przez dominującą (patriarchalną) historiografię.

W sposób zwięzły ujmuje ten postulat Shüssler Fiorenza, podążając za myślą Spender: „Postawmy sprawę jasno. Od wieków kobiety wyrażały wiele takich myśli, które my wyrażamy dzisiaj i które często uważamy za nowe [...]. Istnieją całe dziedziny [nauki], które powstały na podstawie dyskusji na temat męskich pomysłów i idei. Byłoby zatem produktywną zmianą, gdyby kobiety zaczęły opracowywać, przekształcać i tworzyć wychodząc od myśli swoich pramatek"3.

Po drugie, w moich odczytaniach zwracam się w kierunku teorii afektów, (w ujęciu Sary Ahmed i Lisy Blackman5), która uznaje znakowy wymiar doświadczenia, ale i podkreśla jego wymiar afektywny. Uwagę zaś kieruję na retoryczny wymiar użycia emocji w tekście i konstruowanie pamięci

1 D. Spender Women of Ideas (And What Men Have Done to Them): From Aphra Behn to Adrienne Rich, Routledge \& Kegan Paul, Boston 1982.

2 E. Shüssler Fiorenza Transforming the Legacy of The Woman's Bible, w: Searching the Scriptures. A Feminist Introduction, ed. by E. Shüssler Fiorenza, SCM Press, New York 1993, s. 1-24.

3 E. Shüssler Fiorenza Transforming the Legacy of The Woman's Bible, s. 2. "[Let's] make it clear. For centuries women have been saying many of the things that we are saying today and which we have often thought as new [...]. There are industries built upon the discussion of men's ideas, and for women it would be a productive change to build upon, elaborate and modify the ideas of our foremothers".

4 S. Ahmed Cultural Politics of Emotion, Routledge, New York-London 2004.

5 L. Blackman Immaterial Bodies. Affect, Embodiment, Mediation, Sage, Los Angeles-LondonNew Delhi-Singapore-Waszyngton 2012. 
jako kulturowej mediacji kondycji afektywnej człowieka. Ujęcie kwestii genealogii i pamięci kobiet w porządku religii z perspektywy teorii afektów otwiera nowe możliwości interpretacyjne i pozwala przekroczyć utrwalone dychotomie: kobiecy/męski, wewnątrz/na zewnątrz, centrum/peryferia, opór/asymilacja.

Począwszy od anachoretek pierwszych wieków naszej ery, przez kobiety "poświęcone Bogu": mniszki, męczennice, mistyczki i tercjarki średniowieczne i wczesnonowożytne, aż po współczesne nam teolożki feministyczne możemy zdefiniować trwałą potrzebę nazywania źródeł wiary chrześcijańskiej poprzez doświadczenie/doświadczenia i z perspektywy kobiet. Wychodząc od tego założenia, w tym artykule chciałabym wskazać kilka przykładów „niekanonicznych” odczytań pamięci i genealogii, ukazujących ciągłość dziedzictwa kobiet w chrześcijaństwie i proponujących nowe w znaczeniu przekształcające, zmieniające lub zrywające z obowiązującą wykładnią wiary - odczytanie miejsca kobiet w porządku teologicznym, antropologicznym i eklezjologicznym. Przyjrzę się zwłaszcza zmiennym znaczeniom godności i skromności (dignitas i modestia) jako narzędziom retorycznym $\mathrm{i}$ jako manifestacjom semantyczno-somatycznym w konstruowaniu funkcji i pojęcia autorki ${ }^{6}$. Pozwoli mi to zadać pytania i, być może, zarysować paralele między strukturą elokucyjną i afektywną biblijnych egzegez zakonnic wczesnonowożytnych (i tu odniosę się do przykładu Valentiny Pinelo, augustianki rekoletki z Sewilli przełomu XVI i XVII stulecia) i interpretacji współczesnych teolożek feministycznych (i tu dla zachowania spójności kontekstu hiszpańskojęzycznego zajmę się myślą Marii Pilar Aquino i Esperanzy Bautisty Parejo). U podłoża tej refleksji sytuuję potrzebę zadania pytań nie tyle o miejsce kobiet w porządku religijnym, ile o ich przestrzeń w chrześcijańskiej koncepcji Boga. Formuła ta odnosi się do swoiście biblijnej perspektywy - podążam tu za argumentacją Claude'a Tresmontanta7 - i jednocześnie poszerza granice wyznaczone przez androcentryzm i jego krytykę. Nie koncentruje się na przeciwstawianiu sobie kulturowej hierarchii pozycji marginalnej i centralnej, niższej i wyższej. Przestrzeń bowiem to coś więcej niż miejsce. Przestrzeń to system relacji.

6 Retoryka nie jest konstruktem czysto myślowym i abstrakcyjnym, ale pozostaje w głębokiej i wzajemnej relacji z doświadczeniem cielesnym podmiotu. Ucieleśnienie - w tym upłciowienie - i znaczenie tej płci nadane w kulturze warunkuje poruszanie się/dostęp do konwencji retorycznych, recepcję, krytykę, obieg czytelniczy.

7 C. Tresmontant Esej o myśli hebrajskiej, Znak, Kraków 1996, passim. 
Ksiega Chwalebnych Uczynków i Doskonałości Wspaniałej Świętej Anny autorstwa Valentiny Pinelo ${ }^{8}$ jest tekstem synkretycznym: wiąże elementy mariologiczne i chrystologiczne w formie traktatu doktrynalnego o macierzyństwie pierwszych kobiet w historii chrześcijaństwa. Do egzegezy i hermeneutyki biblijnej włącza passusy moralizatorskie, hagiograficzne, formacyjne, etymologie, interpretację kabalistyczną i astrologiczną. Porusza również zagadnienia prawa wskazując na historyczny charakter dyskursu biblijnego, w tym praw małżeńskich, dziedziczenia i lewiratu. Księga została opublikowana w 1601 roku w Sewilli i, na ile szeroko pozwoliły mi sięgnąć moje badania, stanowi najwcześniejszy znany nam przykład drukowanej egzegezy i hermeneutyki biblijnej kobiecego autorstwa. Autorka wyprowadza w niej genealogię kobiecej mądrości i sprawczości. A dokładniej, przedstawia model macierzyńskiej genealogii chrześcijan, wywodząc ją od mądrości przypisanej św. Annie, która nazwana jest „matką Matki”, czyli Marii Dziewicy, a przez co „babką Chrystusa i całej ludzkości"’.

Tym tekstem autorka zabrała głos w jednej z kluczowych wczesnonowożytnych debat teologicznych dotyczących kwestii Niepokalanego Poczęcia Najświętszej Marii Panny ${ }^{10}$. Siostra Pinelo włączyła się w dyskusję, której oś sporu przebiegała między stanowiskami zwolenników niepokalanego poczęcia (tzw. inmakulistów, których pogląd o uprzednim uchronieniu Marii od grzechu pierworodnego, o szerokim poparciu społecznym, reprezentowali

8 V. Pinelo Libro de las Alabanças y Excelencias de la Gloriosa Santa Anna [...], Clemente Hidalgo, Sevilla 1601.

Tamże, prolog, [b.s.].

Niepokalane Poczęcie jako dogmat wiary katolickiej został ustanowiony w XIX wieku (bulla Ineffabilis Deus z 8 grudnia 1854 roku). Jednak monarchowie terytorium Iberyjskiego bronili tej prawdy wiary już od czasów wizygockiego króla Wamby w VII wieku. Później także królowie Ferdynand III Święty, Jakub I Zdobywca, Jakub II, Karol I i Filip II Habsburgowie byli szczególnie oddani kultowi Purísima Concepción, używając tej prawdy wiary w swoich kampaniach wojennych. Od XIV wieku ustanowiono bractwa ku czci Niepokalanego Poczęcia, a w XVI wieku wraz z Soborem Trydenckim obrona NP ożyła z nową siłą. Jako prawda wiary Niepokalane Poczęcie Najświętszej Marii Panny miało swoich zwolenników również wśród przedstawicieli uniwersytetów: Kolonii, Sorbony i Walencji. Dwa główne miasta hiszpańskie, w których rozwijał się konflikt na skalę masową to Granada i Sewilla. W 1613 roku po oficjalnej prośbie inmakulistów skierowanej do papiestwa o zdyskredytowanie makulistów uzyskano odnowienie konstytucji Sykstusa IV poprzez encyklikę Regis pacifici wydaną przez Pawła V, która zapewniała wolność kultu we wszystkich uroczystościach odnoszących się do Niepokalanego Poczęcia Marii. Za panowania Filipa IV Habsburga spór pozostawał otwarty mimo bulli z 1655 roku upoważniającego do oddawania czci Niepokalanej. 
franciszkanie, do których z czasem dołączyli jezuici i kler) i jego przeciwników (tzw. makulistów, głównie dominikanów, podążających za myślą Akwinaty i santificatio in utero). Z początkiem wieku XVII na ziemiach hiszpańskich owa kontrowersja teologiczna nabrała cech dyskusji powszechnej, angażując liczne grupy społeczne, zwłaszcza w Sewilli i Grenadzie, i doprowadzając do wybuchu ulicznych protestów, aktów przemocy i fal prześladowań. Kulturowe znaczenie tego konfliktu stosunkowo szybko zostało przejęte przez dyskurs czystości krwi (limpieza de sangre), tak że zaczęto utożsamiać bycie dobrym Hiszpanem (ser un buen español) z byciem inmakulistą. W świetle tych uwarunkowań zabranie głosu w niniejszej dyspucie było krokiem koniecznym, jeśli chciało się zaznaczyć swoją obecność w debacie teologicznej i dewocyjnej danego momentu, ale i ryzykownym. Ryzyko było większe, gdy obrony tej prawdy wiary podejmowała się kobieta i mniszka, podwójnie naznaczona przez kategorie ciszy i podporządkowania, bowiem jak wskazuje jedna z linii nauczania Pawła Apostoła: „Mulier in silentio discat” „Mulier in ecclesia taceant" $i$ „Doceri autem mulieri non permito" (1 Tym 2,11; 1 Kor, 14:34; 1 Tym 2,12).

Valentina Pinelo, mniszka jednego z najbardziej elitarnych klasztorów Imperium Hiszpańskiego XVI i XVII stulecia, św. Leandra w Sewilli, w swojej hermeneutyce biblijnej proponuje przewartościowanie roli Marii w historii chrześcijaństwa. Taka strategia lektury była szczególnie częsta wśród autorek religijnych zajmujących stanowisko w kwestiach teologicznych, które - jak pamiętamy - aż do połowy wieku XX i postanowień Soboru Watykańskiego II były dla kobiet formalnie niedostępne. Gertruda Wielka z Helfty (OSB, 1256-1301/1302), Izabela de Villena (OSC, 1430-1490) czy Maria od Jezusa z Ágredy (OIC, 1602-1665) ${ }^{11}$ w kulcie maryjnym i próbach jego reinterpretacji dostrzegły korzystną drogę, aby uprawomocnić swoje autorstwo i skonstruować silną pozycję autorki, rysując analogię z postacią Marii na podstawie pojęcia ciała upłciowionego. Swój głos przedstawiały jako replikę słów Świętej Dziewicy, które znajdowały pełnię swoich sensów właśnie przez ich równie dziewicze i kobiece ciała. Jednak Pinelo "narusza scenę teologiczną" swojego czasu w sposób bardziej ewidentny, wkraczając w przestrzeń debaty

11 Należy wskazać, że Mistyczne Miasto Boga Marii od Jezusa z Ágredy (1655-1660) stanowi jedno z najważniejszych hermeneutycznych odczytań życia Marii z Nazaretu. Jest rodzajem metanarracyjnej refleksji nad tą postacią rozumianą jako wzór kobiecej świętości, ale także autorytet wywodzący się z jej roli Theotokos. W tym sensie imitatio mariae jako jeden ze wspólnych elementów duchowej refleksji autorek religijnych ustala zależność między kobiecością, macierzyństwem, mądrością i nauczaniem. 
i proponując interpretację nie na podstawie doświadczenia duchowego i cielesnego, czyli odwołania się do argumentum ad experientiam, jak w przypadku wspomnianych mistyczek, ale też męczennic i profetek, ale negocjując pozycję auctoritas jako teolożki. Autorka broni genealogii Jezusa w linii matczynej, dając pierwszeństwo nie tylko postaci Marii, ale jej matki, Anny. Proponuje rodzaj inwersji dziedziczenia, gdzie świętość córki rzutuje na postać jej matki. Kwestionuje w ten sposób, lub co najmniej odsuwa na drugi plan, ojcowską konceptualizację religii judeochrześcijańskiej. Jednak w odróżnieniu od argumentacji mariologicznych znanych z dzieł innych autorek zakonnych okresu Valentina Pinelo skupia się na zagadnieniu mądrości św. Anny i wyróżnia relację między matką a córką, wyprowadzając z niej macierzyńską genealogię biblijną. Wykorzystując polifoniczność wizerunku św. Anny w ówczesnej kulturze literackiej i wizualnej, przekształca porządek ojcowski nadany Trójcy Świętej w trynitarny porządek macierzyński czy, innymi słowy, proponuje genealogię i chronologię biblijną opartą na dziedzictwie matki.

W tym miejscu chciałabym wskazać, że historia św. Anny, którą autorka wyprowadza ze źródeł apokryficznych: Protoewangelii Jakuba (ok. 140-170) i Ewangelii Pseudo-Mateusza (620-625) oraz m.in. Złotej Legendy Jakuba de Voragine i Speculum Historiae Wincentego z Beauvais, a także z XIV-wiecznej Vita Christi Ludolfa von Sachsena i, za jego pośrednictwem, Historii Wspaniałej św. Anny Pedro Orlando de Cartujano, funkcjonowała w kulturze europejskiej jako symbol polisemiczny (i odnoszę się do terminologii zaproponowanej przez Victora Turnera ${ }^{12}$ ). Jak podkreślają Katleen Ashley i Pamela Sheigron w publikacji Interpreting Cultural Symbols. Saint Anne in Late Medieval Society ${ }^{13}$, przedstawienia ikonograficzne tej postaci umożliwiały wielość interpretacji, niejednokrotnie wzajemnie się wykluczających. Dość wspomnieć tu najważniejsze z tych przedstawień, jak: Trinubium odnoszące się do trzech małżeństw Anny z Joachimem, Kleofasem i Salome; Sacra Parentela, czyli Wielką Świętą Rodzinę ukazującą Maryję z Dzieciątkiem, Annę, matkę Marii, jej siostry Marię Salome i Marię Kleofasową z ich rodzinami, oraz dalszych krewnych: dalej, Annę Samotrzeć/Samotrzecią obrazującą Annę z małą Marią z Nazaretu i dzieciątkiem Jezus czy wreszcie, mniej znaną, Anną Samoczwartą wprowadzającą do wcześniejszego przedstawienia postać matki Anny, Emerencję.

12 V. Turner The Forest of Symbols: Aspects of Ndembu Ritual, Cornell University Press, New York 1967 , s. 24 .

13 K. Ashley, P. Sheigron Interpreting Cultural Symbols. Saint Anne in Late Medieval Society, University of Georgia Press, Athens-London 1990. 
Jedna z linii interpretacyjnych tych wizerunków, pozornie niewskazująca na kategorie płci i gender, objaśniała je jako sposób na „neutralne” przedstawienie dynastii, rodowodu i dziedziczenia. Inna, w sposób oczywisty naznaczona kwestią tożsamości płciowej, podkreślała rolę Anny jako matki Marii Dziewicy. Obydwie jednak posługiwały się kategoriami płciowymi w ramach porządku androcentrycznego i heteronormatywnego. W momencie reprezentowania kategorii męskocentrycznych, a pozornie neutralnych,jak patrylinearny model dziedziczenia, Anna stawała się przezroczystym nośnikiem wartości, takich jak rodowód, dynastia i, co za tym idzie, prawo i pamięć. W momencie jednak, gdy zaczynała być interpretowana przez pryzmat swojego upłciowionego ciała i jego rodzicielskiej potencjalności, symbolika ta stawała się wyłączna i wykluczająca: mogła dotyczyć jedynie kobiet i być ograniczona do macierzyństwa. W swoim odczytaniu Pinelo wykorzystuje obydwie te tradycje, sięgając do biblijnych obrazów „dzielnej niewiasty”/mulier fortis i rysując analogie z postacią Anny, matki Samuela czy Sary, matki Izaaka, wskazując na, jak moglibyśmy powiedzieć z perspektywy studiów kulturowych, relacyjne i dynamiczne tożsamości: matki i córki, nauczycielki i uczennicy, oddanej Bogu i będącej z nim w dialogu, walczącej i dającej świadectwo wiary i wreszcie, matriarchini „stojącej u początków wcielenia się Boga poprzez narodzenie z Dziewicy, tej która poprzedza wcielenie Słowa i objawienie się zbawczej treści"14 .

W proponowanej przez Pinelo interpretacji na szczególną uwagę zasługuje prolog dzieła, gdzie Pinelo negocjuje swoją pozycję autorki-teolożki wobec dyskursu i wykładni nauczycielskiej Kościoła, których autorytet był uświęcony tradycją i uzusem, a który zamykał przed kobietami przestrzeń debaty teologicznej.

Prolog do Księgi Chwalebnych Uczynków i Doskonatości Wspaniałej Świętej Anny przekracza typową funkcję perswazyjną exordio. Jest przestrzenią negocjowania i dialogu, w której krzyżują się głosy i dyskursy kultury oficjalnej. $\mathrm{Z}$ jednej strony traktaty doktrynalne, patrystyka, moralistyka, czyli teksty, które konstruowały modelową kobiecość i uprawomocniały doksę niższości społecznej i intelektualnej kobiet. Z drugiej wielość głosów Valentiny Pinelo jako autorki, czytelniczki i interpretatorki, które podawały w wątpliwość ową doksę. I właśnie te dwa ostatnie głosy: czytelniczki i interpretatorki, chciałabym rozwinąć w mojej dalszej myśli.

Praktyka czytelnicza w żeńskich zakonach w XVI i XVII stuleciu rozwijała się w sposób bardziej niezależny od kierunków polityki kontrreformacyjnej 
niż było to w przestrzeni świeckiej. Komunikacja literacka między zakonami, dzięki wewnętrznym sieciom cyrkulacji i recepcji literatury, wpływała na tworzenie się wspólnot czytelniczych i pierwszych literackich środowisk kobiecych o własnej tradycji i znaczeniu wykraczającym poza klasztorne mury. Jako przeorysza jednego z ważniejszych kulturowo i ekonomicznie centrów religijnych regionu Andaluzji Valentina miała dostęp do wielu dzieł dewocyjnych, teologicznych, duchowych i filozoficznych, które wykorzystała w swojej lekturze Biblii z pozycji kobiety i mniszki. Jeśli przyjmiemy za Dianą Fuss $^{15}$, że „akt czytania jako kobieta” zachodzi w punkcie granicznym interpretacji tekstu, kiedy odczytanie przekracza czy odrywa się od ustalonego wzorca i sensu utrwalonego przez androcentryczny model lektury Valentina w swojej egzegezie biblijnej proponuje odczytanie nienormatywne. Kiedy, w trakcie argumentacji „jest zaskoczona” niedocenioną obecnością kobiet w Piśmie Świętym, gdy podkreśla brak uznania sprawczości i roli kobiet w konstruowaniu pierwszego rodu chrześcijan i odrzuca takie interpretacje, które deformują bądź nie doceniają kobiecych postaci biblijnych, wprowadza w przestrzeń hermeneutyki swoje doświadczenie upłciowione - w znaczeniu społecznym i kulturowym - i przekształca w ten sposób dany sens tekstu. W związku z tym odrzuca samouprawomacniający się system myślenia o niższości intelektualnej i społecznej kobiet i ich nieobecności w procesie historycznym. Dalej, konfrontuje się z wynikającą z tego symboliczną pustką, którą następnie oswaja i przejmuje już jako autorka, kiedy stawia sobie wyzwanie przepisania/napisania na nowo genealogii Chrystusa z perspektywy dziedziczenia i pamięci matki:

Ewangelista święty Mateusz zaczyna pierwszy rozdział swojej ewangelicznej historii pisząc, księga pokolenia Jezusa Chrystusa, syna Dawida, syna Abrahama kontynuując aż do Jakuba, Ojca Józefa męża Marii, z której narodził się Jezus, nazwany Chrystusem, jednak zgodnie z Wiarą Chrześcijańską, nie był on synem Józefa, ani spłodzonym z mężczyzny, ale przez działanie Ducha Świętego, Wiecznego Ojca narodził się w swojej istocie z Dziewicy Marii, względem ciała: zatem zdaje się, że w tym miejscu święty Ewangelista się myli, co zaraz zostanie dowiedzione. ${ }^{16}$

D. Fuss Leer como una feminista, w: Feminismos literarios, Arco/Libros, Madrid 1999, s. 127-145. 
Wyznaczenie nowego horyzontu interpretacji niesie ze sobą konieczność poszukiwania nowego języka, za pomocą którego można by nazwać genealogię mądrości kobiecej, której Valentina czuje się kontynuatorką. W tym celu Pinelo odwołuje się do dwóch tradycji, które pozwalają jej przedstawić własną interpretację Pisma i Tradycji apostolskiej i negocjować granice ortodoksji, której nowe ramy wyznaczone zostały przez postanowienia Soboru trydenckiego. Przede wszystkim odnosi się do wizerunku św. Anny nauczycielki znanego z przedstawień wspomnianej Sacra Parentela i Anny Samotrzeć. Na tej podstawie konstruuje model czytelniczki/uczennicy i nauczycielki prawd wiary, który umożliwia jej wymienność tych perspektyw i pozycji. Temat św. Anny nauczającej był szczególnie chętnie podejmowany przez malarzy i rzeźbiarzy sewilskich tego okresu. To José Montes de Oca, Juan de Roelas, Bartolomé Esteban Murillo i Diego de Velázquez, poprzez swoje dzieła, umocnili w kulturze regionu model świętej matki-nauczycielki, która uczy czytać swoją córkę, a czasem i swojego wnuka. Autorka augustiańska wykorzystała wizerunek Anny nauczycielki i Marii uczennicy, wskazując na książkę i pismo jako prawomocne medium przekazywania wiedzy między kobietami. Modelowy symbolizm tej sceny posłużył Pinelo jako rama pojęciowa, aby utrwalić sens i typologię zrozumiałą i możliwą do przekazania innym czytelniczkom i kobietom-odbiorczyniom Pisma.W tym sensie odwołanie się do "chrześcijańskiego czytelnika” (cristiano lector), które rozpoczyna prolog, otwiera się na inne interpretacje i znaczenia. Obrona nauczycielskiej roli kobiet poprzedza odczytanie genealogii mądrości kobiecej, która opiera się na ciekawym retorycznym użyciu dychotomii godności i skromności (dignitas i modestia). Pozwala autorce zaznaczyć swoją pozycję jako interpretatorki i teolożki, która robi użytek ze słowa pisanego i która potrafi je odszyfrować.

W tym celu Pinelo przede wszystkim stosuje „retorykę zaciemniania” (rhetoric of obfuscation), i odnoszę się tu do klasyfikacji zaproponowanej przez Alison Weber w analizie dzieł Teresy od Jezusa ${ }^{17}$, kiedy to wskazuje na cudowny charakter swojego autorstwa (autoría maravillosa) uprawomocniony

que se llama Christo, pues siendo como es Fé Católica, que no fue hijo de Joseph, ni engendrado de varón, sino por obra de el Espíritu Santo, de el Eterno Padre nacido esencialmente primero que de la Virgen, según la carne: parece pone aquí el sagrado Evangelista un confuso, y en breve quedara averiguado".

17 A. Weber Teresa of Avila and the Rhetoric of Femininity, Princeton University Press, PrincetonNew Jersey 1996. 
autorytetem zewnętrznym wobec tekstu, czyli wolą Bożą i Jego majestatem. Dalej, akceptuje pogląd o kobiecie jako bycie podporządkowanym lub nie-bycie, który to następnie, w zręcznej retorycznej wolcie, wykorzystuje na swoją korzyść. Przekształca go bowiem w rodzaj proton pseudos, ponieważ, zastanówmy się, czy może przemawiać jak erudyta ten, który pozbawiony jest władz poznawczych i symbolicznej obecności?

Pokornie proszę, aby moja książka nie straciła na wiarygodności i znaczeniu, i temu, kto powie, że brakuje jej wartości, ponieważ nie posiada autora dyplomowanego w naukach świętej teologii, odpowiem, że Pismo Święte posiada taki autorytet, że nie mogę dezawuować go ja, nie posiadając wiedzy o temacie [tu nieprzetłumaczalna gra słów: falta de sujeto to brak wiedzy, ale też brak podmiotu, nie-bycie] czy nie studiując. ${ }^{18}$

Oryginalność wywiedziona etymologicznie z początku jako źródła myśli i ustanawiająca nową wiedzę prowadzi do przewagi w dziele Valentiny Pinelo inventio nad imitatio. Autorka umiejscawia impuls swojego pisania, które przedstawia za pomocą pojęcia walki, w miłości „najodważniejszym uczuciu ze wszystkich naszej duszy: które podejmuje największe wyzwania" zatem "teraz z tego zadania obiecuję sobie wyjść zwycięsko". Za uprawomocnienie służy jej auctoritas tematu, który podejmuje; odwołanie się do pozycji mecenasa-kardynała i siostrzeńca - Dominika Pinelo, który podjął się publikacji dzieła, oraz sam Bóg i Maryja Dziewica, którzy nie tylko są gwarantem prawdy zawartej w tekście, ale „uczynią go znanym”, co jest celem wyznaczonym sobie przez Valentinę Pinelo jako autorkę w prologu dzieła.

Dalej siostra Pinelo rozwija hermeneutyczne odczytanie tytułu nadanego Annie „matki Matki Boga”.Ten przydomek, używany w debacie inmakulistów przez m.in. Pedro de Ribadeneyrę, Diego Muñoza de Ocampo czy Miguela Cida, a który po sukcesie dzieła Valentiny podejmie za nią m.in. Pedro de Alva i Astorga (Militia Inmaculate Conceptionis, 1633), podkreślał rolę pośrednictwa Anny w procesie odkupienia ludzkości. Jednakże Pinelo zaznacza jego wartość jeszcze dobitniej poprzez dodanie Annie cech boskich niebezpiecznie zbliżając jej interpretację ku herezji i idolatrii:

18 V. Pinelo Libro de las Alabanças, prolog, [b.s.]: „Humildemente suplico que no pierda crédito y opinión este libro, y a quien dixere que le falta valor, por no tener un auctor graduado en sacra Theologia: respondo que la sagrada Escriptura tiene tanta auctoridad consigo que no la puedo desautorizar yo, por la falta del sujeto, o por no haber estudiado". 
Twój dar Pani konkuruje z darem Wiecznego Ojca, jeśli On dał swego Syna Jedynego na odkupienie ludzkości Ty dałaś swoją jedyną córkę, aby była pośrednikiem tak wielkiego Dobra, i aby ród ludzki otrzymał remedium, zatem Bóg i Ty Pani ofiarowaliście Światu zbawienie i w ten sposób dałaś Pani Wiecznemu Ojcu małżonkę, nieskończonemu i wszechmocnemu, i ona narodzona z Twojego łona i wychowana i wykarmiona Twoimi niebiańskimi piersiami, i Ty Pani dałaś mleko, które przekształcone zostało w krew, aby z niej i z Twojego ciała przyjął ciało jedyny syn Boży. ${ }^{19}$

Jak już wspomniałam, język mariologiczny, który tworzy pole semantyczne dla tej argumentacji, był często wykorzystywany przez pisarki religijne i mistyczki, ponieważ otwierał możliwość włączenia doświadczenia kobiecych upłciowionych ciał w konstruowanie i interpretację źródeł wiary. Autorka mogła znać i zaadaptować poetykę i metaforykę maryjną z popularnej wówczas wśród żeńskich wspólnot Vita Christi Izabeli de Villena i innych tekstów dewocyjnych, które odnosiły się do modelu imitatio Mariae. Jednak w tekście Pinelo model ten został poszerzony o relację między matką i córką przedstawioną jako analogiczna (!) do relacji Boga Ojca i Syna Bożego.W ten sposób podważał czy destabilizował hierarchię trynitarną interpretowaną przez tradycję wyłącznie w kategoriach ojcostwa i synostwa.

Na uwagę zasługuje również wykorzystanie symboliki kobiecych płynów, tak często pojawiające się w tekstach mistyczek i męczennic w opisach ich drogi imitatio Christi $^{20}$, natomiast stanowiące pewne novum w tekście teologicznym. W interpretacji Pinelo kobiece mleko i krew są cielesnymi płynami

19 V. Pinelo Libro de las Alabanças, 278r: „Vuestra dadiva haze competencia con la del eterno padre; quien si el dio su unigénito hijo para redimir los hombres, vos le disteys vuestra hija, para que fuesse el medio de tanto bien, y tuviesse remedio el género humano, por lo que Dios y vos señora disteys a el mundo [...] y assí que al eterno padre disteys esposa siendo infinito, y de infinita grandeza, y ella nacida de vuestro vientre, y criada a vuestros dichosos pechos, $y$ dandole vos la leche que convirtió en sangre, para que de ella y de vuestra carne se vistiesse el unigénito hijo de Dios".

20 Figura Chrystusa-karmiciela, wykorzystywana w mistycznym imaginarium, odnosiła się do symbolu Chrystusa jako Dobrego Pelikana znanego ze średniowiecznych bestiariuszy. Eucharystycznie karmi On chrześcijan pokarmem ze swoich piersi i krwią przelaną na krzyżu. Taka paralela mogła w pełni zrealizować się jedynie poprzez materialność kobiecego ciała. Tylko to ciało bowiem mogło „karmić, krwawić i odradzać się w swoim życiu iżyciu drugiego człowieka" (B. Ferrús Antón Heredar la palabra: Vida, escritura y cuerpo en América Latina, Universidad de Valencia, Valencia 2005, s. 151). W ten sposób mistyczki przekształcały konkretne doświadczenie kobiecego ciała w źródło i uprawomocnienie swojego pisania. 
kontinuum: symbolicznym gwarantem wejścia i próbą twórczego przekształcania męskiej przestrzeni nauczania i interpretacji, ale też stwarzania, które opiera się, jak wskazywała Kristeva ${ }^{21}$, nie na ciągłości, lecz na rozdzieleniu. Tą myślą Pinelo otwiera również drogę do poszukiwań etymologicznych: w jej interpretacji grecki czasownik gennao, będący rdzeniem genealogii, odnosi się do „bycia na początku”,,dawania początku”, ale też „rodzenia”. W tym sensie przywódcą rodu, od którego wyprowadza się linię genealogiczną, jest matka, która daje początek kolejnym pokoleniom w żywej tkance rodzinnych zależności.

Przyjrzyjmy się teraz porządkowi argumentacji przedstawionej przez Pinelo. Metodologicznym punktem wyjścia interpretacji jest hermeneutyka podejrzeń, jaką autorka stosuje wobec źródła: „Uwierzcie bez wątpienia, że Pismo Święte nie bez wielkiej tajemnicy unieważniło uwielbienie wspaniałej świętej Anny"22. Jednocześnie to właśnie nieobecność Anny w kanonie Pisma Świętego umożliwia autorce sięgnięcie do źródeł apokryficznych i takie ich skompilowanie, które posłuży w argumentowaniu za sprawczością i rolą Świętej dla chrześcijaństwa. Dalej autorka wskazuje na nieumiejętność Apostołów i Doktorów Kościoła rozeznania się w tej materii, bowiem „żaden z nich nie był w stanie pojąć tak subtelnego i synkretycznego języka" ${ }^{23}$, a tym samym „nadać Świętej właściwe dla jej wielkości imię"24. W związku z tym proponuje siebie samą jako możliwą interpretatorkę, odnosząc się z tą prośbą bezpośrednio do Świętej: „O najradośniejsza Anno, jaki to tytuł dały Tobie Niebiosa? [...] Jakie to imię jest tak wyjątkowe? Spójrzmy, czy ma jakąś etymologię tak jak pozostałe: zaproponujmy, o Pani, jakąś jego interpretację"25. Obrona godności i świętości Anny była jednym z powodów cenzury tekstu, do czego wrócę jeszcze w dalszej części wywodu. Pamiętajmy, że uzgodnienia Soboru Trydenckiego odnosiły się krytycznie do kultu świętej nieobecnej w Biblii, ale chętnie obrazowanej przez źródła apokryficzne, dostrzegając w nim zatarcie granic kanonu czy nawet otwarcie na herezję. Jednak argumentując za uznaniem wielkości tej postaci, Pinelo nie ogranicza się do

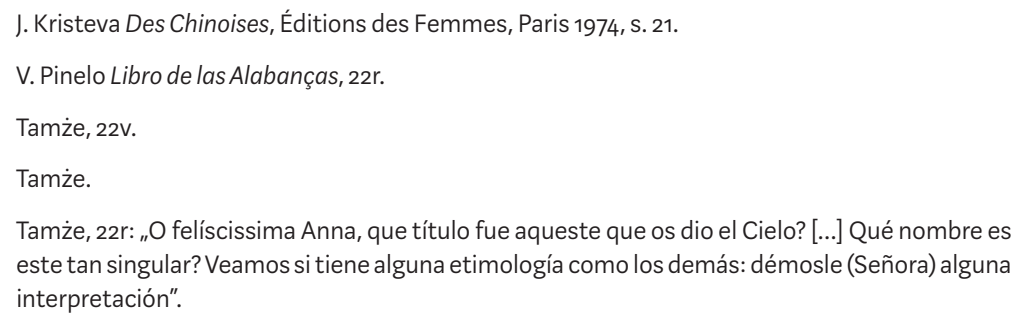
este tan singular? Veamos si tiene alguna etimología como los demás: démosle (Señora) alguna interpretación". 
dowartościowania jej roli wśród świętych Kanonu rzymskiego. Wskazując na przyczyny nieobecności kobiecych genealogii w porządku religijnym, wkracza poprzez egzegezę nie tylko w przestrzeń teologii - rozumianej jako mowa o Bogu (theologeia) - ale też soteriologii i antropologii. Jej odczytanie i uznanie roli i sprawczości pierwszych kobiet chrześcijaństwa: Anny i Marii, opiera się na przedstawieniu ich udziału we wcieleniu (nie tylko materialnym, ale i intelektualnym) Boga-człowieka i, tym samym, w zbawieniu ludzkości:

Najważniejszym zadaniem jakie Niebiosa powierzyły ziemi [...] i największą godnością spośród wszystkich było być Matką Boga, a zatem także być matką Matki Boga: i ta prawda nie może być podważona. [...]. Być Matką Boga było największym honorem, który pokonał Aniołów w ich łasce i roli, i w czystości przewyższył Cherubinów, i w prawie Serafinów i w ogniu miłości: jest największym ze wszystkim: była bowiem światłem i geniuszem dla Patriarchów i Profetów; Nauczycielką dla Apostołów, przykładem i siłą dla Męczenników, Panią Kapitan dla Dziewic, mądrzejszą od wszystkich Spowiedników i Doktorów [...] ona była ponad wszystkimi: bardziej subtelna, bardziej uczona od wszystkich Kaznodziejów. [...] ale Ty Wspaniała Anno dałaś klejnot tak cenny, że całe złoto Ziemi nie jest w stanie się z nim równać, bowiem w nim zawarło się bogactwo Niebios: in quo sunt omnes thesaum: wyzwolenia uciśnionych i zmartwychwstania zmarłych; i tak poprzez ten rodowód został rodzaj ludzki zbawiony i zostało dane mu nowe życie. ${ }^{26}$

Wcielenie, tak jak przedstawia je myśl chrześcijańska, i podążam tu za argumentacją Claude'a Tresmontanta, to coś więcej niż sam fakt narodzin. Z Dziewicy ma narodzić się Bóg Logos - Posłane Słowo - ma objawić się pewna treść. Wątek ten rozwinę szerzej w dalszej części artykułu. Tu jednak

26 Tamże, 20r-20v i 280v. „El mayor oficio que el cielo repartió y dio en la tierra [...] y la mayor dignidad entre todas ellas, fue ser madre d[e] Dios y assi mismo ser madre de la Madre de Dios: y esta verdad no tiene contradición. [...]. El ser Madre de Dios fue mayor alteza, excedió a los Ángeles en el oficio y en la gracia, y en la pureza a los Cherubines, y en la licencia a los Serafines y en el fuego de amor: es mejor que todos: pues fue lunbrera de los Patriarcas y Profetas, Maestra de los Apóstoles, exemplo y fortaleza de los Mártires, Capitana de las Vírgenes, más sabia que todos los Confessores y Doctores [...] ella lo fue de todos, y más elegante, y más erudita que todos los Predicadores. [...] pero vos gloriosa Anna disteys una joya tan preciosa, que todo el oro de la tierra no le yguala, pues en ella se atesoró el del cielo: in quo sunt omnes thesaum: la qual fue para la redempción de captivos y resurreción de muertos; y assí quedó por este medio todo el linaje humano redimido y con nueva vida". 
chciałabym zaznaczyć, że wcielenie jako „wejście Boga w cielesną strukturę osoby i strukturę ludzkiej myśli"27 poprzedza gotowość do Jego przyjęcia. Zarówno maryjne fiat, jak i Niepokalane Poczęcie Marii w łonie Anny, są dla Pinelo gwarantem tej gotowości, podjęciem - wciąż rozgrywającego się między Bogiem a człowiekiem - dialogu.

W świetle takiej hermeneutyki, której pole semantyczne wyznacza argumentacja Redemptoris Mater, sytuując się na obrzeżach ortodoksji Kościoła potrydenckiego retoryka prologu Ksiegi nabiera dodatkowego wymiaru strategicznego. Jeśli, zgodnie z tym, co proponuje Barthes, „rolą prooemium jest, do pewnego stopnia, egzorcyzmowanie arbitralnego charakteru każdego początku" ${ }^{28}$, aby wkroczyć w tekst w funkcji autorki Pinelo jako pisarka musiała ustanowić dyskursywną strategię, która chroniłaby ją przed możliwymi oskarżeniami o plagiat, rozumiany jako uzurpowanie sobie słowa, ale też przestrzeni i władzy, do których jako kobieta nie miała dostępu. Pinelo, znając z pewnością przypadki Isabel Ortiz, Marii Cazalla, Marii od św. Dominika czy Teresy od Jezusa, których interpretacje teologiczne zawiodły je przed trybunał Świętego Oficjum, musiała mieć na uwadze, że ani królewski imprimatur, ani kościelny mecenat nie będą w stanie zapewnić jej ochrony, jeśli jej interpretacja zostanie uznana za heretycką. W związku z tym pierwsze zdanie prologu, jakie proponuje, a więc zdanie, które egzorcyzmuje wkroczenie w horyzont oczekiwań czytelnika, jest próbą usprawiedliwienia się wobec możliwych oskarżeń i przeciwników. Rozpoczynając tekst sentencją Terencjusza Quot capita, tot sententiae, która poprzedza alegoryczne przedstawienie ignorancji i niewiedzy, obrazujący relatywny charakter ludzkich opinii, Pinelo tworzy rodzaj „filtru bezpieczeństwa”. Stara się zrelatywizować potencjalne oskarżenia, bowiem „ile głów, tyle opinii, i jeśli każdy kto przeczyta moją książkę wyrazi swój o niej pogląd to potrzeba cierpliwości"29. W ten sposób ogranicza możliwą cenzurę tekstu do tak błahej kwestii jak „różnica poglądów”. W sprawny i skuteczny sposób dekonstruuje ostrze krytyki, przewidując możliwe oskarżenia i wskazując na ich stereotypowy charakter.

I przekonana jestem, że wiele będzie zdań i nie wszystkie będą przemawiać na moją korzyść, bowiem kto nie będzie oceniać mojej intencji, co

C. Tresmontant Esej o myśli, s. 170.

R. Barthes La antigua retórica, Eds. Buenos Aires, Barcelona 1982, s. 67.

29 V. Pinelo Libro de las Alabanças, prolog, [b.s.]: "Cuantas fueren las cabeças tantos han de ser los
pareceres, y si cada uno que leyere mi libro á de dar su decreto, paciencia”. 
się chwali, potępi mnie za odwagę, ośmieliłam się bowiem podjąć się tak wielkiego wyzwania, będąc kobietą i bez wykształcenia i bez umiejętności i żyjącą w zamknięciu. ${ }^{30}$

Dyskryminujące uprzedzenia płciowe mówiące o kobiecie jako istocie podporządkowanej i o zakonnicy jako nieuczonej są wyśmiane poprzez sprawną antyfrazę dignitas i modestia, jeśli czytamy je przez pryzmat całości tego erudycyjnego dzieła, które w samym indeksie źródeł zawiera 422 odniesienia do Starego i Nowego Testamentu, kilkadziesiąt odniesień do filozofów starożytnych, tekstów Ojców i Doktorów Kościoła, jak: Listy św. Hieronima, Historia Eclesiastica Nicephorusa Callistusa Xanthopulusa, teksty Epifaniusza z Salaminy, Jana z Damaszku, bizantyjskiego hagiografa Symeona Metafrastesa czy św. Cyryla. Nie brakuje też odwołań do źródeł uznanych za heretyckie bądź znajdujących się w procesie weryfikacji Świętego Oficjum, jak chociażby Vida Teresy od Jezusa i Cántico espiritual Jana od Krzyża. Równie istotne jest samookreślenie się Pinelo jako autorki i interpretatorki: „kiedy piszę, czuję, że latam poprzez kolejne miejsca Pisma [...] wybrałam pisanie dla własnej satysfakcji, zapisuję tu moje myśli i moje słowa"31.

$\mathrm{Z}$ drugiej strony cenzura, z jaką spotkał się tekst będący już w obiegu czytelniczym i posiadający królewski imprimatur, wskazuje na zasięg i znaczenie publikacji. Anonimowy autor, prawdopodobnie jezuita i cenzor kwalifikowany, w carta dilatoria ${ }^{32}$ zarzuca Pinelo zuchwałość (atrevimiento) związaną zarówno z podjętym tematem (Inmaculada), wskazanymi źródłami (apokryfy), ale także z samą "czelnością by jako kobieta zabierała głos w sprawie doktryny". I tak nawet gdy refutatio autorki skierowane jest przeciwko „herezji luterańskiej", wpisując się w dominującą retorykę kontrreformacyjną, cenzor nie zgadza się na jej wejście w przestrzeń teologiczną, bowiem: „replikować nie jest właściwym dla kobiet" ${ }^{\text {"33. }}$.

30 Tamże, prolog, [b.s.]: „Y persuadida estoy a que á de haver variedad de pareceres y no todos han de ser en mi favor, pues quien no juzgare mi intención que es bueno, condenará por atrevimiento, el aver osado acometer a tan alta empresa, siendo muger y sin letras, y con poca havilidad, y encerrada".

Tamże, prolog, [b.s.]: „y quando escrivo me hallo bolando con algún lugar de escriptura [...] é tomado este medio para satisfación de mi gusto, empleado en ella mis pensamientos y palabras". Leandro de Sevilla, British Library, Ms. Add. 20915, ff. 346-348. 
Podsumowując i raz jeszcze wskazując na retorykę prologu w kontekście całości dzieła, bliższy insinuatio niż klasycznemu proœmium, prolog Księga Chwalebnych Uczynków i Doskonałości Wspaniałej Świętej Anny posłużył Pinelo jako przestrzeń negocjowania swojej pozycji autorki i uprawomocnienia autorytetu symbolicznego jako pisarki i teolożki. Napisany, jak sama mówi, w „bestialskim języku kobiety” zapowiadał traktat erudycyjny i złożony wywód egzegetyczny, wskazujący na macierzyńską genealogię Jezusa. Aby "podjąć się tak wielkiego zadania”, Pinelo skonstruowała funkcję-autorki na podstawie silnego paradoksu polegającego na obronie braku kompetencji za pomoca falsa modestia i humilitas i jednocześnie udowodnieniu swojej szerokiej wiedzy jako owocu autodydaktyzmu, poszukiwania prawdy i poznania. W ten sposób zakwestionowała znaczenie doksy. Na początku pierwszego rozdziału autorka ostrzega czytelnika, że jej tekst będzie jak „płaski śpiew”, że jej głos nie będzie „ani głosem Anioła, ani mężczyzny, ale kobiety, która nie może podnieść tonu ni melodii, tak jakby chciała"34. Jednak nie rezygnuje $\mathrm{z}$ tego wyzwania. Zgodnie z horacjańską sentencją sapere aude postanawia „zabrać głos z ziarnem soli teologii na języku”35 z przekonaniem, że „rozum i wola (jeśli coś są warte) zrekompensują wszystkie błędy"36.

Spójrzmy teraz na ten temat z perspektywy szerszego kontekstu historii Kościoła katolickiego, w ramach którego Pinelo pisze swoją egzegezę. Jest to moment krytyczny rozłamu jedności zachodniego Kościoła, kiedy to reakcja kontrreformacyjna i postanowienia Soboru Trydenckiego zaznaczają początek logiki pojmowania Kościoła jako oblężonej twierdzy, która utrzymała się co najmniej do Soboru Watykańskiego II. Z kolei w wyniku i w krytycznej odpowiedzi na to ostatnie zgromadzenie ekumeniczne XX wieku sprecyzowane zostały postulaty teologii wyzwolenia i różne stanowiska, niejednokrotnie wzajemnie się wykluczające, teologii feministycznych. Natężenie tych głosów w ciągu ostatnich dwudziestu lat, z których dwa chciałabym przytoczyć w dalszej części artykułu, może być dowodem na to, że Kościół katolicki znajduje się po raz kolejny w punkcie granicznym/przełomowym swojej historii. Wychodząc od definicji teologii rozumianej jako fides quaerens intellectum (wiary, która szuka zrozumienia) teologia feministyczna może być zdefiniowana jako teologia krytyczna, która - w słowach benedyktyńskiej

V. Pinelo, Libro de las Alabanças, 2V: „ni será de Ángel, ni de hombre, sino de muger que no puede alçar la boz, ni subir el punto como quisiera". 
mniszki doktor farmacji i teologii Teresy Forcades i Vila - rodzi się z doświadczenia sprzeczności, czy to o charakterze ontologicznym, czy epistemologicznym. Wskazuje na jednostronność biblijnych interpretacji, która prowadzi w praktyce do istotnych przesunięć na mapie kulturowych pojęć i wartości. Konstruuje rzeczywistość wiary jako rzeczywistość asymetryczną, w której centrum stoi pierwiastek męski. W związku z tym teologia feministyczna - czy to w wydaniu radykalnym czy krytycznym - nie chce być komplementarna do teologii tradycyjnej, którą ocenia jako androcentryczną, ale dąży do stworzenia nowej teologii, historycznie i kulturowo skontekstualizowanej, w której doświadczenia kobiet stanowią centralny locus theologicus. Takie usytuowanie punktu ciężkości refleksji już na wstępie każe zadać nam pytanie, które pozostawiam otwarte, o to czy przy takim założeniu możemy mówić o teologii feministycznej czy raczej bliżej jesteśmy feminizmu czy feminizmów teologicznych.

Trzymając się jednak powszechnie uznanych terminologii między różnymi propozycjami teologii feministycznych, refleksja nad znaczeniem mariologii dla kobiet i Kościoła oraz perspektywa Kościoła na ujęcie praw i obowiązków kobiet, a zatem ich wolności i odpowiedzialności jako osób w jego Magisterium są podejmowane z największą intensywnością. Konfliktowy charakter tego pola namysłu teologicznego wynika zasadniczo z trzech powodów. Po pierwsze, w krajach Europy Zachodniej, w których można by usytuować początki niektórych nurtów teologii feministycznej, po Soborze Watykańskim II mariologia została zepchnięta na dalszy plan refleksji. Po drugie, zarówno charakter ekumeniczny Soboru, jak i samych ruchów feministycznych teologii paradoksalnie utrudnia podjęcie dialogu na tematy maryjne między przedstawicielami Kościołów protestanckich, katolickich i prawosławnych. Ostatecznie, trzeci powód wynika z kontekstu historycznego tradycji maryjnej, w której przez stulecia dawano pierwszeństwo wzorcowemu wizerunkowi Marii jako ucieleśnieniu paradoksalnych ideałów społeczeństwa patriarchalnego uświęcającego macierzyństwo „idealne”, czyli macierzyństwo nienaznaczone utratą dziewictwa. W ten sposób kobietom jako wiernym Kościoła i kobietom teolożkom zamknięto możliwość identyfikacji z kluczową żeńską figurą chrześcijaństwa.

W tak zarysowanej panoramie odczytania Pisma i tradycji, które proponuje María Pilar Aquino ${ }^{37}$ i w niektórych punktach również Esperanza Bautista

37 M.P. Aquino (1992) Nuestro clamor por la vida: teología latinoamericana desde la perspectiva de la mujer, Editorial Departamento Ecuménico de Investigaciones, Costa Rica, San José; M.P. Aqu- 
Parejo ${ }^{38}$, są szczególnie interesujące choć niepozbawione kontrowersji. Ich wspólną matrycą refleksji jest filozofia teologii wyzwolenia z naciskiem położonym na krytyczną refleksję, która ma wyłonić się z zaangażowania w praktykę (ortopraxis, która poprzedza ortodoksję), nad sproblematyzowaniem pojęcia „el pueblo" jako wspólnoty wiernych i przestrzeni/relacji kobiet $\mathrm{w}$ jej ramach. Podobnie jak w teologii wyzwolenia jako prymarne $\mathrm{u}$ obydwu autorek pojawia się pytanie o to, kto jest podmiotem Bożej soteriologii. Jak przedstawia to Aquino: „Podstawowa treść i ostateczna celowość Bożego objawienia jest zawarta w pojęciu zbawienia. [...] zbawienie jest rozumiane przez Latina feminist theology jako wyzwolenie od wszelkiego ucisku. [...] W ten sposób historyczny proces wyzwolenia z ubóstwa, z niesprawiedliwości społecznej i wykluczenia staje się najbardziej skutecznym i wiarygodnym przejawem Bożej soteriologii ${ }^{39}$.

Dla nas, w perspektywie pytań o przestrzeń kobiet w chrześcijańskiej koncepcji wiary, istotne jest, że w refleksji obu autorek możemy dostrzec nieustającą próbę przeformułowania wizerunku Marii i Boga na dwóch płaszczyznach.

Przede wszystkim obydwie autorki podejmują próbę krytyki kategorii allocentrycznych, w których ramy apologetyka wpisała postać Marii z Nazaretu: Matka Naszego Zbawiciela, Opiekunka, Pocieszycielka i Pośredniczka. W ten sposób wyrywają z pozornej oczywistości perspektywę, która definiuje kobietę w kategoriach relacyjnych, nieistniejącą przez siebie samą, ale zwróconą ku innym. Z takiego punktu widzenia pojęcia godności i skromności otrzymują dodatkowe znaczenia, ponad wymiarem środków retorycznych, jaki dominuje w argumentacji Pinelo, ale również w odróżnieniu od znaczeń im nadanych przez tzw. „nowy feminizm” spod znaku Edyty Stein czy "geniuszu kobiecego"

ino Latina Feminist Theology: Central Features, w: A Reader in Latina Feminist Theology Religion and Justice, red. María Pilar Aquino, Daisy L. Machado, Jeanette Rodríguez, University of Texas Press, Austin 2002, s. 133-160.

E. Bautista Parejo Género y eclesiología, w: Cambio de paradigma, género y eclesiología, red. C. Bernabé, Ed. Verbo Divino, Navarra 1998, s. 87-108; E. Bautista Parejo En búsqueda de la justicia perdida, Resistencia y creatividad: ayer, hoy y mañana de las teologías feministas, red. C. Picó Guzmán, Ed. Verbo Divino, Navarra 2015, s. 47-96.

M.P. Aquino Latina Feminist Theology, s. 154: "The core content and ultimate finality of God's revelation is resumed in the term salvation. [...] salvation is understood by Latina feminist theology as liberation from every oppression. [...] Thus the historical process of liberation from poverty, social injustice, and exclusion becomes the most effective and credible manifestation of God's salvation". 
promowanego przez Jana Pawła II m.in. w liście apostolskim Mulieris Dignitatem (1988). Zarówno Bautista Parejo, jak i Pilar Aquino przeciwstawiają się "głównym zaletom kobiecym" przypisanym przez tradycję katolicką Marii, jak: posłuszeństwo, pokora, pasywność, uległość, które to cechy tradycja łączy $\mathrm{z}$ doświadczeniem macierzyństwa widzianym jako jedyne i ostateczne powołanie kobiet. W takim rozumieniu postać Marii była interpretowana jako ucieleśnienie ideału matki, a potencjalność kobiecego ciała, by przyjąć i dawać nowe życie, uznane za jedyną prawomocną drogę jej rozwoju jako osoby. Obydwie teolożki proponują odczytanie "niekanoniczne” dignitas i modestia, odwołując się do dwuznaczności ich sensów ujętych już przez św. Augustyna, który definiował skromność jako rodzaj pokornej dumy. Podążając za tą myślą, przywracają postaci Marii status podmiotu sprawczego niedocenionego również przez wczesne lektury feministyczne Beauvoir (Druga płeć), Cixous (Sorties, w: La jeune née) czy Kristevej (Stabat Mater, w: Histories d'amour), która to pisze "Ciało Marii to ucho [...], łzy i piers" ${ }^{40}$ i które sprowadzały Marię do kategorii nieobecności. W rekonstrukcji podjętej przez Parejo i Aquino nacisk jest położony po pierwsze na uwolnienie Marii z Nazaretu od fałszywych obrazów nałożonych przez androcentryczną tradycję (historycznie uwarunkowanych, kulturowych kategorii kobiecości i macierzyństwa) oraz uwolnienie kobiet od wizerunków maryjnych, które zakładają zawężoną wizję antropologiczną.

Do pewnego stopnia analogicznie jak w latynoamerykańskich nurtach teologii wyzwolenia w swojej argumentacji Aquino podkreśla wagę obrazu Wyjścia w procesie uświadamiania opresji podporządkowanych/kobiet oraz znaczenie pieśni Magnificat następującej jako zwieńczenie dialogu dwóch kobiet: Marii i Elżbiety, jako pierwszej nazywającej Marię poprzez jej wiarę („Błogosławiona jesteś, któraś uwierzyła, że spełnią się słowa powiedziane Ci od Pana", Łk 1,45) i jako pieśni relatywizującej monopol męskiej władzy. Jednakże znaczenie dane Magnificat w interpretacji teologii feministycznej spod znaku teologii wyzwolenia przekracza w znaczny sposób dowartościowanie relacyjnej postaci Maryi jako matki Boga. Postuluje, aby dwie kluczowe wypowiedzi Marii zawarte w Biblii: fiat i Magnificat, odczytywać zawsze we wzajemnym odniesieniu. W przeciwieństwie do dominującej interpretacji uświęconej tradycją, która fiat traktowała jako bierną i uległą akceptację Maria Aquino, podążając za interpretacją Rosemary Radford Ruether i Cathariny Halkes, widzi w niej świadomą i krytyczną gotowość do zaangażowania się, wzięcia odpowiedzialności czy, odwołując się do pojęcia rozwijanego przez

40 J. Kristeva Stabat Mater, w: Histories d'amour, Éditions Denöel, Paris 1997, s. 236. 
takie filozofki jak Adriana Cavarero i Judith Butler, gotowości do udzielenia odpowiedzi Innemu. Ta gotowość na otwarcie się na bliźniego, ujęta w pojęciu responsivness, jest definiowana przez Butler jako

The ethical relation means ceding a certain egological perspective for one which is structured fundamentally by a mode of address: you call upon me, and I answer. But if I answer, it was only because I was already answerable; that is, this susceptibility and vulnerability constitutes me at the most fundamental level, and is there, we might say, prior to any deliberate decision to answer the call. In other words, one has to be already capable of receiving the call before actually answering it. In this sense, ethical responsibility presupposes ethical responsiveness. ${ }^{41}$

Posługując się tą argumentacją, wrażliwość/podatność na zranienie (vulnerability) zostaje przekształcona w źródło sprawczości i siły, natomiast cichą akceptację (fiat) interpretuje się jako odpowiedź daną i możliwą właśnie ze względu na wolność i odpowiedzialność, jakie charakteryzują pojęcie osoby. Tak rozumiane pojęcie fiat poprzedza Magnificat i sytuuje Marię w ramach tradycji profetycznej kobiet Starego Testamentu: Miriam, Debora, Hulda, Anna, matka Samuela uosabiają mesjanistyczne oblicze Izraela i Kościoła. W takiej hermeneutyce biblijnej Magnificat staje się podstawowym tekstem duchowości wyzwolenia, której warunek sine qua non stanowi nawrócenie. Jednocześnie jest to najbardziej upolityczniony tekst Nowego Testamentu: jego wymowa jest głęboko społeczna i radykalna. Łączy krytykę niesprawiedliwości społecznej i duchowości ubogich JAHWE (annawim J H W H) z samym rdzeniem Ewangelii - Dobrej Nowiny o Bogu, który wywyższa ubogich i upokorzonych. W tym sensie Magnificat poprzedza Kazanie na górze, a postać Marii jest odczytana jako pierwsza wywyższona przez Boga. Takie usytuowanie punktu ciężkości interpretacji, jak trafnie zauważa w swojej lekturze postaci Marii z perspektywy teologii feministycznej Elżbieta Adamiak, sytuuje ją w roli pierwszej apostołki, pierwszej, która uwierzyła, pierwszej, która, śpiewając Magnificat, głosi Ewangelię ${ }^{42}$.

41 J. Butler Precarious Life. Vulnerability and the Ethics of Cohabitation, "Journal of Speculative Philosophy", 26 (2), s. 138.

42 Por. E. Adamiak Milczq̨ca obecność. O roli kobiety w Kościele, Biblioteka "Więzi”, Warszawa 1999, s. 99; T. Forcades i Vila La teología feminista en la historia, Fragmenta editorial, Barcelona 2007, s. 81; M.P. Aquino Latina Feminist Theology, s. 133-160. 
Drugą propozycją tak rozumianej hermeneutyki biblijnej jest odnowienie teologii poprzez odnowienie mariologii.W tym sensie Pilar Aquino postuluje, by „kobieca symbolika boskości utożsamiana i przypisywana Marii zaczęła być odnoszona do jej właściwego adresata to znaczy do Boga". Boskość jako transcendentna przekracza płciowość i jest zapisywana za pomocą palimpsestu Di*s (Dios-a) (God/ess), który ma pomieścić/ująć nie tylko to, co jest pojmowane jako męskie i żeńskie w Bogu, ale transcendencję i immanencję, umysł i ciało ${ }^{43}$. Dewocyjność maryjna jest w takim rozumieniu źródłem nowego języka opisującego tajemnicę Boga, natomiast Maria, w zgodzie z dogmatem Soboru Efeskiego jest nazwana Theotokos/Matką Boga ze względu na zawarcie Nowego Przymierza. Jej rola jako „małżonki i matki Nazaretu” wynikają z niego, ale i go przekraczają. Zatem kluczowym pojęciem dla zrozumienia postaci Marii staje się nie macierzyństwo, a wiara. Taka propozycja kwestionuje również ograniczoną wizję antropologiczną kobiety. Otwiera bowiem możliwość nienaturalistycznego ujęcia samego macierzyństwa, podkreślając wolę i myśl, czyn i sprawstwo. Konsekwentnie aspektem, który musi zostać przywrócony w odczytaniach Pisma, jest macierzyńskie oblicze Boga. Jako jego uzupełnienie Aquino i Parejo, podążając za Elizabeth Shüssler Fiorenzą ${ }^{44}$ i Elizabeth Johnson ${ }^{45}$, odwołują się również do tradycji mistyki judeochrześcijańskiej, w której obecność i sprawczość Boga są opisywane za pomocą pojęć dynamicznych lub czasowników: chochma (sophia) - mądrość; Shekhiná - obecność; ruah - Duch Święty i rahamim - miłosierdzie, w którym podkreśla się etymologię pojęcia, która odnosi się do rehem - macicy.Te próby rewizji i odnowienia języka nie poprzestają jedynie na zmianie rodzajników pojęć, ale postulują zmianę sposobu mówienia, a zatem i myślenia o transcendencji - nie zatrzymując się na kategoriach wszechmocy i sprawiedliwości - ale również rozumiejąc transcendencję jako włączoną w tkankę życia, dobrowolnie zależną, ponieważ miłującą ${ }^{46}$.

W świetle tak zarysowanych postulatów interpretacyjnych warto na koniec zadać jeszcze pytanie o to, jak sytuują siebie same - jakie „miejsce” czy

43 M.P. Aquino Latina Feminist Theology, s. 145 i passim.

44 E. Schüssler Fiorenza Bread Not Stone: The Challenge of Feminist Biblical Interpretation. With a New Afterword, Bacon Press, Boston, MA 1984, passim.

E. Johnson The Incomprehensibility of God and the Image of God Male and Female, "Theological Studies" 45 (3), s. 441-465.

46 Por. E. Adamiak Macierzyństwo Boga i Maryi w teologii feministycznej, "Salvatoris Mater" 1/1, S. 256-271. 
„przestrzeń" - dla swojej refleksji konstruują obydwie teolożki. Wydaje się, że kluczem do uchwycenia usytuowania funkcji-autora w tekstach Aquino i Parejo jest rozumienie różnicy i granicy. Ich głos, choć słyszalny (co nie oznacza rozpoznawalny - mający autorytet) przez dominujący dyskurs teologiczny jest głosem "spoza" granic ortodoksji. To usytuowanie na marginesach głównego nurtu refleksji (w słowach Aquino "creative border location") nie stanowi jednak oddzielenia, ale zostaje odczytane jako możliwość przenikania i poszerzania perspektywy. Dla Aquino kreatywne obrzeża są wyborem i otwarciem: „Oznacza to, że decyduję się wejść [...] tam, gdzie odbywa się wzmożony dialog, tam, gdzie powstają relacje, albo tam, gdzie jestem «zarówno-i»"47 48 . I choć, jak uczy nas doświadczenie zdobyte przez historię myśli i praktykę feministyczną, tego rodzaju usytuowanie zawsze niesie za sobą pewne ryzyko zamknięcia w "single-sex getto" użyte świadomie i strategicznie pozwala wyjść poza utrwalone dychotomie centrumperyferia, wskazując na ruch jako podstawową kategorię chrześcijańskiej antropologii i eklezjologii. W tym celu Parejo, interpretując i dopowiadając myśl Phyllis Trible (God and the Rhetoric of Sexuality, 1978), przywołuje obraz Biblii jako pielgrzyma i biblijnego tekstu jako wędrującego słowa. Parejo podejmuje ten gest wędrówki, której ostatecznym celem jest przemiana poprzez wiarę ${ }^{49}$.

Na zakończenie chciałabym wrócić do znaczenia godności i skromności (dignitas i modestia) w retoryce tekstów. Captatio benevolentiae i fałszywa skromność (falsa modestia) są elementami emotywnymi (animos imperelle) dispositio. Prolog, wraz z epilogiem, ustanawiają przestrzeń interpelacji, poruszenia, uwiedzenia i wymuszenia potulności sędziego/czytelnika.W tym sensie przekraczają logos i działają bezpośrednio w przestrzeni afektów. Z tych dwóch części taxis znaczenie proæmium jest gwałtowniejsze, ponieważ, idąc za myślą Barthes'a, to prolog ustanawia „pierwsze słowa, które przecinają wirtualną

Aquino konfrontuje to pojęcie z pojęciem „Nepantla” wyprowadzonym z myśli Glorii Anzaldúa, które to w języku nahuatl oznacza twórczo i sprawczo ujęty status "kreatywnych obrzeży". "Nepantla" to: „in-between state, that uncertain terrain one crosses when moving from one place to another, when changing from one class, race, or gender position to another, when traveling from the present identity into a new identity" (G. Anzaldúa, The Gloria Anzaldúa Reader, red. AnaLouise Keating, Duke University Press, Durham-London 1998, s. 165 abundant dialogue occurs, there where relationships happen, or there where I am «both-and»". 
nić opowieści bez początku"50. Owo „zaczynam mówić” zawiera w sobie również sens „udomawiania”: czynienia własnym tego, co obce, poprzez słowo i emocje. Dla teolożek, których symboliczna wartość dyskursu nie była i nie jest rozpoznawana jako równoważna $\mathrm{z}$ wartością dyskursu męskiego, wstąpienie w biblijną hermeneutykę wciąż zdaje się mieć charakter prologu. W materii wiary zabranie głosu ma również dodatkowy, gwałtowny wymiar: potrzebę już nie tylko, aby wziąć w posiadanie daną przestrzeń, ale by znaleźć język. Jest podjęciem ryzyka obudzenia tego co nieznane/nienazwane, bez gwarancji, że będzie się potrafiło nazwać/dać początek swojej myśli.

\section{Abstract}

\section{Julia Lewandowska}

UNIVERSITY OF WARSAW

"She Was Both the Mother of the Virgin Mary and the Grandmother of God and Humankind": Female Genealogies in Interpretations of Sources of Faith

The memory of Christian communities, negotiated and constructed in the first centuries of our era, is an androcentric one, as the canon of the Good News and its interpretations by the Fathers and Doctors of the Church have excluded women's voices from the dominant narrative of faith. However, women's words and agency constitute an irreducible part of Christian heritage. Lewandowska analyses several examples of women theologians early modern and contemporary - who search for biblical genealogies. She highlights the changing meanings of dignitas and modestia as rhetorical tools as well as the semantic and somatic manifestations used in constructing the notion of the author and the authorfunction by these writers. Lewandowska's discussion of the re-evaluation of the place of women in the history of the Catholic Church and its Magisterium draws on the theory of affect. This opens up new interpretative possibilities that go beyond conventional dichotomies such as female/male, centre/periphery, resistance/assimilation.

\section{Keywords}

feminist theology, Mariology, exegesis, rhetoric, affect, Christian monasticism, female genealogies

R. Barthes La antigua retórica, s. 67. 